\title{
PSA Level Ten to Fifty
}

National Cancer Institute

\section{Source}

National Cancer Institute. PSA Level Ten to Fifty. NCI Thesaurus. Code C124830.

A blood concentration of prostate specific antigen between 10 and $50 \mathrm{ng} / \mathrm{mL}$. 